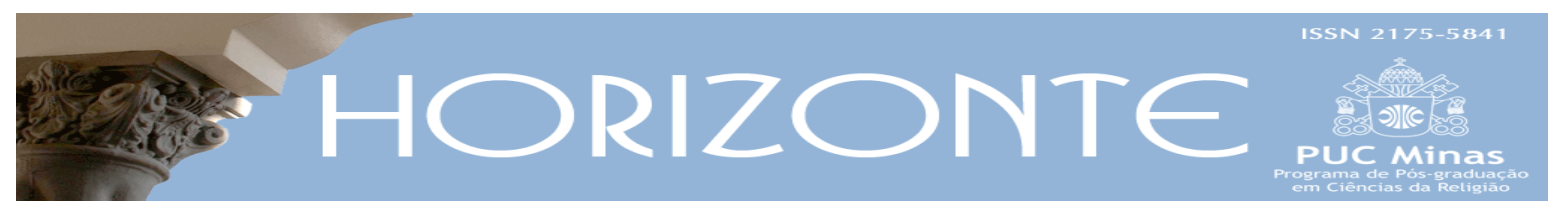

Temática Livre - Artigo Original

@-

DOI - 10.5752/P.2175-5841.2017v15n47p905

\title{
O Conceito de Ética no Candomblé
}

\author{
The concept of ethics in Candomblé
}

Volney José Berkenbrock*

\begin{abstract}
Resumo
Este artigo irá apresentar os pressupostos para se pensar o conceito de ética na religião do Candomblé e de sua visão de mundo. Na visão do Candomblé, a existência é dividida em dois níveis: o Orum e o Aiyê. A realidade finita, individualizada e histórica é a existência Aiyê. Mas esta é uma existência que tem sua origem no Orum, a realidade permanente. No Orum tudo existe sempre. Quem administra as existências individualizadas são as forças chamadas de Orixás. Cada ser humano é filho ou filha de um Orixá. A ética no Candomblé se constrói a partir da relação entre o adepto e o seu Orixá. Não há assim no Candomblé uma ética de valores ou de princípios. A ética no Candomblé é uma ética relacional. Ela depende da relação de cada pessoa com o seu Orixá e da manifestação deste. Depende também do estágio de iniciação do fiel, pois cada estágio gera diferentes obrigações. A relação do adepto com o seu Orixá tem por objetivo alcançar uma existência em equilíbrio, numa busca que é constante e dinâmica.
\end{abstract}

Palavras-chave: Candomblé, Ética, Orixás, loruba, Religiões afro-brasileiras

\begin{abstract}
This article will present the presuppositions to think about the concept of ethics in the religion of Candomble and its worldview. In Candomblé's worldview, the existence is divided into two levels: the Orum and the Aiyê. The finite, individualized and historical reality is Aiyê existence. But this is an existence that hat its origin in Orum, the permanent reality. In Orum everything always exists. Who govern the individualized existences are the force called Orixás. Every human being it son or daugther of an Orixá. Ethics in Candomblé is built on the relation between the believer and his Orixá. There is no ethics of principles or values in Candomblé. Ethics in Candomblé is a relational ethic. It depends on the relation of each person with his Orixá and the manifestation of this. It depends also on the stage of iniciation of the believer, bacause each stage generates different obligations. The relation of the believer with his Orixá is aimed at achieving an existence in equilibrium, in a search that is constant and dynamic.
\end{abstract}

Key words: Candomblé, Ethics, Orixás, loruba, Afro brazilian religions.

Artigo submetido em 16 de abril de 2017 e aprovado em 23 de setembro de 2017.

* Doutor em Teologia (Faculdade de Teologia Católica da Universidade Federal de Bonn, Alemanha - Rheinische-Friedrich-WilhelmUniversität 1995), professor do PPG em Ciência da Religião da UFJF. País de Origem: Brasil. E-mail: volney@itf.org.br

Horizonte, Belo Horizonte, v. 15, n. 47, p. 905-928, jul./set. 2017 - ISSN 2175-5841 


\section{Introdução}

Discutir a relação entre ética e religião é entrar numa seara muito ampla e de muitas possibilidades de delimitações. Logo de início é preciso, portanto apresentar quais delimitações se pretende fazer aqui. Dentro deste amplo espectro da ligação entre religião e ética, no que tange à religião, iremos ter como base a religião afro-brasileira do Candomblé. O conceito de ética é uma temática relativamente pouco trabalhada nos estudos sobre o Candomblé. Assim, não há ainda um lastro bibliográfico específico tão extenso no qual se possa apoiar. Não se trata, pois tanto de discutir diferenças de interpretações ou correntes de ética nesta tradição religiosa, mas muito mais indicar princípios a partir dos quais seria possível visualizar onde estaria ancorada uma ética pensada a partir do Candomblé. A isto irá basicamente se dedicar o texto.

Duas advertências se fazem necessárias ainda nesta introdução. A primeira delas é o fato de que não existe "o Candomblé”. Existem Candomblés. Mas para não complicar demasiadamente as coisas, aqui iremos utilizar a palavra no singular, tentando apontar sempre para o modo de pensar que lhe seja próprio e original, conscientes de que esta tradição religiosa está, no seu desenvolvimento no Brasil, cruzada por muitas influências de outras tradições religiosas, mormente de origem católica e espírita. Não será objeto deste texto abordar estas influências, mesmo que digam respeito por vezes a elementos éticos. Também não iremos abordar as diferentes origens culturais africanas que irão compor os Candomblés. Iremos tomar como base o Candomblé jeje-nagô, por vezes também chamado de Candomblé queto que, como afirma Prandi, “é aquele que passará a representar o modelo típico de candomblé no Brasil” (1991, p. 16). Uma segunda advertência que se quer aqui fazer a título introdutório é o fato de que em momento algum se tem a intenção de apontar ou averiguar até que ponto estes elementos básicos de uma ética pensada a partir do Candomblé são de fato sempre vividos pelos membros desta religião. Uma possível distância entre a proposta ética de determinada 
tradição religiosa e o que os seus fieis de fato vivem, é provavelmente uma constante nas religiões e não seria o Candomblé uma exceção.

\section{1 Ética implica numa concepção de ordem do mundo}

É comum um certo linguajar que na associação entre religião e ética, faça também uma associação entre religião e controle de seus membros no sentido de imposição ou recomendação de limites de ação que a religião prescreve ou então de costumes ou comportamentos desejados ou indesejados. Nesta ideia um tanto simplificada de ética religiosa aparece um elemento a se chamar a atenção e que é a nosso modo de ver um tanto comum às compreensões de ética: a ideia de que há uma ordem considerada correta ou boa ou justa, mesmo que este bom ou justo possa ser entendido de diversas formas ${ }^{1}$ Ético é tudo aquilo que está conforme esta ordem. O que não está é aético ou antiético. Há assim um pressuposto à ética que é o pressuposto de um referencial que representa o modo de ser, de agir, de portar-se e comportar-se tido como em ordem, isto é, que se adequa à compreensão de ordem que subjaz ao respectivo conceito ético. Entendido como sistema cerceador ou como sistema que proporciona segurança no agir e por isso promotor do bem, por detrás do conceito de um sistema ético há claramente a ideia de uma ordem que seja referência e na qual o comportamento possa se medir para saber de sua retidão. Onde estaria ancorado este sistema?

Ao mesmo tempo, há igualmente uma expectativa no senso comum de que quem vive no seguimento da religião, deva pautar sua conduta por uma postura ética. Isto se exige ou espera principalmente de quem é publicamente conhecido pela sua participação religiosa - mormente as lideranças. Novamente aparece aqui a ideia de um padrão de conduta a ser seguido quando se trata de uma pessoa ligada à religião. Independentemente, pois de se entender que a ética é submissa à religião, isto é, que a religião determina o padrão de comportamento de vida de ${ }^{1}$ Antônio Marchionni (2010), em sua obra "Ética: a arte do bom", fez um estudo perpassando muitas escolas de pensamento e
proposições de éticas filosóficas mostrando-as justamente a partir do ponto de vista de que são propostas "do bom". 
seus seguidores ou de se entender que a quem segue uma religião, isto implica um determinado comportamento ético, ou seja, da religião submissa à ética, subjaz a estas compreensões o pressuposto de uma ordem (um modo correto). Aparece da mesma forma a pergunta pelo onde estaria ancorada esta compreensão de uma ordem subjacente, se inclusive a religião a ela se submeteria.

Assim, o conceito de ética não está ligado somente à ideia de um modo de conduta tido como bom ou correto ou justo ou natural ou humano, mas à ideia de que há um padrão de referência, uma ordem por detrás desta ordem comportamental aparente. Ou seja, por detrás da ideia de ética, está uma ideia de cosmos (de mundo organizado). Dito, pois diretamente: toda concepção de ética exige uma visão de mundo e nela se baseia. Não há conceito ético que não seja reflexo de uma cosmovisão. E isto independe de ser uma visão de mundo abrangente ou restrita, orgânica como um sistema total ou fragmentada conforme interesses. Há sempre um conceito de ordem (cosmos) por detrás de todo conceito ético. E este conceito não é fixo nem unificado na história da humanidade. Cada tradição cultural foi elaborando e reelaborando permanentemente sua compreensão de ordem e consequentemente, seu conceito de ética² ${ }^{2}$

O grande mestre chinês Confúcio já a seu tempo enfrentara a situação de colocar ordem na cidade, quando fora nomeado seu administrador:

Ele baixou regulamentos firmes para a alimentação dos vivos e para o enterro dos mortos. Velhos e jovens recebiam comida diversificada, fortes e fracos tinham funções diferenciadas, homens e mulheres andavam separados nas ruas. Coisas abandonadas não eram deixadas pelos caminhos [...] O Duque Ting falou ao Mestre K'ung e disse: "Como ficaria se aplicássemos as vossas medidas ao governo do Estado de Lu?” Mestre K'ung respondeu: "A todo o mundo elas seriam aplicáveis, não somente a Lu” (KRAMERS, 2000, p. 182).

Nesta pequena passagem da biografia de Confúcio, fica clara a noção de que a ordem das coisas do dia a dia tem por detrás uma ordem geral, que "a todo o

\footnotetext{
2 Para a questão da formação da ética nas diversas culturas recomendo Henrique Dussel que apresenta um panorama resumido da “história mundial das eticidades" (2012, p. 19-88).
} 
mundo seria aplicável”. É justamente esta concepção de uma ordem segundo a qual inclusive todo o mundo funcionaria que é um ponto de partida importante para se pensar a relação entre ética e Candomblé. As religiões carregam consigo concepções ou visões de mundo. Não iremos adentrar aqui nesta discussão da relação entre religião e visão de mundo: nosso foco será o de perseguir esta ideia concretamente no sistema religioso do Candomblé3.

Para se adentrar numa reflexão sobre a ética no Candomblé, necessário se faz então primeiro pensar que esta religião é herdeira de uma determinada visão de mundo. A pergunta pela ética no Candomblé precisa começar então pela pergunta sobre a cosmologia que esta tradição religiosa carrega. A posição do ser humano, sua forma de vida e de ação são vistas posteriormente como elementos dentro desta visão geral de mundo. De modo que uma cosmologia implica necessariamente uma antropologia.

\section{A visão de mundo dos iorubanos: o sistema Orum-Aiyê e Olorum}

O sistema religioso do Candomblé que se formou no Brasil é uma herança da escravidão. Os milhares de escravos traficados da África ao Brasil (e às Américas) como mão-de-obra cativa eram portadores não somente de força de trabalho, mas também de múltiplos sistemas culturais, conforme a sua origem. Um grupo cultural significativo que aportou no Brasil como escravo é o composto pelos iorubanos, também chamados de Nagô (MATTOSO, 2016, p. 272). A visão de mundo deste grupo foi formar a base da religião do Candomblé que aqui no Brasil se organiza institucionalmente a partir do início do século XIX.

Um elemento básico da cosmovisão iorubana é a ideia dos dois níveis da existência. Um deles é denominado Orum e o outro Aiyê. Tudo o que existe, está

\footnotetext{
3 Para um estudo mais amplo sobre a temática da ética e suas diversas implicações, recomendo a obra organizada por Torres (2014), "Manual de Ética - Questões de ética teórica e aplicada".
} 
nestes níveis, dos quais fazemos aqui uma breve apresentação4.

Orum é a totalidade da existência. Em Orum tudo se origina e nele tudo permanece. Orum é a existência originante, primordial, matriz, possibilitadora. Aiyê é a existência originada, fenomênica, histórica, perceptível, temporal. Assim a realidade de nossa existência é uma realidade descendente de uma outra forma de realidade, a forma Orum. Esta realidade-origem não é uma realidade do passado ou distante de nossa realidade. Ela é permanentemente originadora. A forma Orum é a possibilidade do existir: algo só passa a existir de fato por que é possível que isto exista. Num exemplo, talvez muito simples, mas claro: nasce um coqueiro no jardim de minha casa. Este fato só acontece porque esta possibilidade existe. Mas ao mesmo tempo, ao nascer um coqueiro, continua existindo a possibilidade de nascerem outros coqueiros. Então a existência de coqueiros como possibilidade permanente é a existência Orum. O coqueiro concreto que nasceu no jardim é a existência Aiyê. Por detrás de toda realidade concreta e individualizada na história está esta realidade sempre-possibilitadora. Orum é o termo utilizado para indicar esta realidade da qual toda a nossa realidade se origina e descende:

O òrun é o espaço sobrenatural, o outro mundo. Trata-se de uma concepção abstrata de algo imenso, infinito e distante. É uma vastidão ilimitada - ode-òrun - habitada pelos ara-òrun, habitantes do òrun, seres ou entidades sobrenaturais. [...] o òrun era uma concepção abstrata e, portanto, não é concebido como localizado em nenhuma das partes do mundo real. O òrun é um mundo paralelo ao mundo real que coexiste com todos os conteúdos desse. Cada indivíduo, cada árvore, cada animal, cada cidade etc. possui um duplo espiritual e abstrato no òrun (SANTOS, 2012, p. 56).

O pressuposto do conceito Orum é o de que toda a nossa realidade é uma realidade-acontecimento, onde as existências são manifestações (fenômenos) de uma forma de existência fonte de tudo (e fonte permanente). A existência humana e tudo o que lhe diz respeito (seu desenvolvimento, sua relações, suas capacidades,

\footnotetext{
${ }^{4}$ Quem talvez por melhor tenha exposto e discutido esta compreensão iorubana da existência em dois níveis foi Juana Elbein dos Santos, no capítulo IV ("Sistema religioso e concepção do mundo: Àiyé e Òrun") de sua obra "Os Nago e a Morte", publicada em 1975 e reeditada até a presente data. Ao respectivo capítulo desta obra remeto aqueles que quiserem se aprofundar na temática: SANTOS, 2012, p. 55-75.
} 
suas realizações, seus sentimentos, suas vontades, seus inventos e construções, sua disposição e sua corporeidade) bem como todas as existências da natureza (animais, vegetais, minerais), em seu estar no tempo só existem a partir do Orum.

Esta ideia de que as coisas só existem porque é possível que existam parece à primeira vista um tanto simplista e óbvia. Encerra, entretanto alguns elementos que são importantes para a reflexão em torno da ética no Candomblé: em sendo Orum a existência-princípio, a forma Orum de existência é a forma referencial. Tudo está no Orum e assim esta forma de existência é absoluta e referência para a existência derivada, a nossa existência concreta. Como veremos adiante, disto resulta, por exemplo, a importante atividade no Candomblé que é o sistema divinatório. Por ele se procura olhar para dentro do Orum, ou seja, olhar as referências para a existência. Outro elemento interessante, neste contexto de se pensar ética, é que as existências concretas não são acontecimentos ex nihil. Não há criação do nada, e com isto não há criador. As existências são realizações de possibilidades sempre existentes. Com isso não há nenhum merecimento do existir. Existir é realização de possibilidade.

Na mitologia iorubana há uma figura acima de Orum e Aiyê, que a tudo teria assim disposto, chamada de Olorum ou então Olodum ou Olodumare, conforme o subgrupo linguístico daqueles povos 5 . Esta figura não tem na prática religiosa quase nenhuma função. Seria apenas o possibilitador ou iniciador do sistema, mas não interventor. $\mathrm{Na}$ religião do Candomblé não são realizados a ele quaisquer rituais. A existência ocorre na intersecção e dinâmica entre Orum e Aiyê e os elementos ali envolvidos, o que não é o caso de Olorum.

O acontecimento concreto de uma possibilidade de existência é expresso na cosmovisão iorubana pelo conceito Aiyê. Aiyê é a existência histórica, fática, limitada no tempo e no espaço. Sua existência é uma realização concreta do Orum

\footnotetext{
${ }^{5}$ Os iorubanos têm uma complexa mitologia transmitida geralmente de forma oral dentro das comunidades, o que faz com que existam múltiplas versões dos mesmos mitos. Pierre Verger (1997a) foi um dos que por primeiro publicou no Brasil uma coletânea destes mitos em "Lendas Africanas dos Orixás". Mas foi Reginaldo Prandi (2001) que realizou um trabalho monumental de reunir cuidadosamente e publicar uma enorme coletânea destes mitos em "Mitologia dos Orixás".
} 
não apenas em sua originação, mas em todo o seu desenvolvimento e em seu acontecer. Cada acontecimento é em princípio uma concretude limitada do Orum. Disto resulta que a existência é um sistema dinâmico de relação permanente entre a forma Orum e a forma Aiyê de existir. A existência só acontece na dinamicidade desta relação. E o que dinamiza esta relação é um sistema de trocas, de oferta e devolução. A manutenção da existência depende desta dinâmica de troca entre os níveis Orum e Aiyê. E ela só existe propiciamente se acontecer numa relação de equilíbrio. A busca e manutenção do equilíbrio entre Orum e Aiyê é certamente a grande razão de ser da religião do Candomblé. O elemento realizador do equilíbrio é chamado de Axé. O termo tem significados bastante amplos, e pode designar tanto uma tradição específica da linhagem de algum terreiro de Candomblé (tal terreiro é do Axé do Gantois, quer dizer, este terreiro descende da linhagem do terreiro baiano do Alto do Gantois), bem como ser usado como uma saudação pelos adeptos das religiões afro-brasileiras (Axé pra você, que quer dizer mais ou menos “desejo energias boas pra você"). Mas no sistema religioso ele significa especificamente "força sagrada dos orixás; força vital que move o mundo" (PRANDI, 2005, p. 304). Chegamos aqui a mais dois elementos-chave para a discussão do conceito de ética no Candomblé: o conceito de equilíbrio entre os dois níveis da existência (Orum e Aiyê) e o Axé como a força sagrada ou vital que mantém o sistema existencial funcionando de forma equilibrada.

Mas para poder adentrar melhor no detalhamento desta relação de equilíbrio e do papel do Axé neste sistema, é preciso entender que a relação entre Orum e Aiyê não é algo genérico, ela é bastante específica e detalhada. E é desta especificidade e detalhamento que brotam elementos para se pensar numa ética desta nesta religião.

\section{Os Orixás: as forças inteligentes primordiais da existência individual}

$\mathrm{Na}$ cosmovisão iorubana, toda a existência concreta e histórica é uma existência descendente da existência genérica ou abstrata - que a tudo possibilita e 
é a forma Orum de existir. E afirmamos anteriormente que o todo existe de forma dinâmica, equilibrada. Equilíbrio este proporcionado pelo Axé. Esta descrição é, porém um tanto abstrata para se chegar às existências concretas individualizadas que conhecemos. As existências concretas ocorrem pelas forças ou princípios conhecidos como Orixás. Os Orixás são as forças que regem todas as existências concretas. Se na mitologia Olorum é o possibilitador do sistema Orum-Aiyê, mas não tem qualquer intervenção na existência, quem desempenha este papel de administrar a existência e fazer com que ela aconteça são os Orixás. Diferentemente do distante Olorum, os Orixás são onipresentes no sistema religioso do Candomblé: tanto nos rituais, quanto na natureza e no ser humano. Os Orixás, estes sim, são o alvo e as figuras centrais das ações de culto; eles são o eixo central em torno do qual gira a vida religiosa no Candomblé. E em torno deles é que irá se formar a noção de ética nesta religião.

A função própria e originária bem como a imagem que se tem dos Orixás é a de mediadores ou talvez melhor dito, de administradores da existência no Aiyê. Aos Orixás confiou Olorum a responsabilidade sobre o universo. O direito de existência dos Orixás está ligado, na concepção mitológica do Candomblé, a esta função mediadora. Se o Orum é a existência genérica e abstrata, esta passa a acontecer à medida que os Orixás a fazem nascer. A palavra Orixá contém em si o termo Ori, que comumente é traduzido por inteligência, mas pode significar também tanto cabeça, como nascimento. Os três termos são aqui correlatos. Os Orixás são as forças que regem a inteligência das existências individuais, são suas cabeças e lhes proporcionaram o nascimento individualizado. O nascimento de cada ser humano se dá pela condução do Orixá, justamente através do Ori: “A cabeça é a primeira parte do corpo que vem ao mundo, abrindo caminho para as demais" (JAGUN, 2015, p. 29). Assim entende-se que os Orixás são as forças da natureza que regem, que administram, que conduzem cada existência individual através de seu Ori. A tradição nomeou, individualizou, personalizou os Orixás, atribuindo a cada qual determinadas especificidades ou responsabilidades na existência. Desta forma à força que faz surgir, crescer e conduzir as árvores, por exemplo, dá-se o nome de 
Ossaim; a força dos rios e sua dinâmica recebe o nome de Oxum; já a força que rege os metais é chamada de Ogum. E assim por diante. Todas as coisas estão sob a regência ou condução de algum Orixá.

A mitologia foi pródiga em construir individualidades em torno da figura de cada Orixá. Assim eles têm histórias de existências, tem relacionamentos entre si, formam famílias. São mais próximos de alguns e não se dão com outros. Mas também têm cores preferidas, têm comidas que lhes agradam e outras que eles detestam. Cada Orixá tem algum comportamento que lhe é típico, representam certas aptidões ou virtudes. São igualmente tanto irascíveis e amáveis, como companheiros e vingativos. Toda a natureza está sob a regência de algum Orixá. Dado que tudo o que existe está como possibilidade no Orum, os Orixás não só se fazem presentes pelas existências individuais em si, mas também de todas as coisas que cercam a história de cada existência. Isto é especialmente importante quando se pensa no ser humano.

Se cada existência individualizada da natureza está sob a regência de algum Orixá, o mesmo acontece com os seres humanos. $O$ nascimento, o desenvolvimento, o modo de ser de cada pessoa está sob a regência de algum Orixá específico. E aqui nos aproximamos do conceito central para a ética do Candomblé: a relação dos indivíduos com os seus Orixás.

\section{Os seres humanos: filhas e filhos dos Orixás}

Cada ser humano é filho ou filha de um determinado Orixá. Esta é uma compreensão básica para a religião. Isto não é tudo o que define o ser humano. A antropologia religiosa do Candomblé é uma temática ampla e já abordada em outro estudo (BERKENBROCK, 2014). Mas para a temática da ética no Candomblé, a ideia da filiação do ser humano em relação aos Orixás tem um papel fundamental: esta filiação define tanto o modo de ser como o modo de agir e igualmente o modo 
de estar no mundo de cada ser humano. Primeiramente é preciso esclarecer que esta filiação não é entendida na religião como uma escolha da pessoa, nem como algo que possa ser trocado durante a vida. A filiação ao Orixá dá-se junto com o nascimento e será uma característica de toda a vida. Em boa parte do Candomblé se entende que cada ser humano além de ser filho de um Orixá principal, o seu Olori (literalmente "senhor da inteligência" ou respectivamente da cabeça ou do nascimento), também é filho de um segundo Orixá, chamado de Juntó. Este modo de entender parece ser uma invenção brasileira e não um hábito entre os iorubanos na África; situação esta atribuída ao fato de que nem todos os Orixás iorubanos cultuados na África tiveram continuidade de culto no Brasil. Assim, algumas características de filiações de determinados Orixás cujos cultos não transpuseram o Atlântico foram recuperadas interpretando numa filiação dupla (Olori e Juntó) ou até múltipla para uma mesma pessoa ${ }^{6}$.

O que interessa aqui na compreensão de que cada ser humano é filha ou filho de um determinado Orixá é relacionar isto com a questão da ética. Dois são os elementos essenciais a serem apontados neste particular. O primeiro deles é o fato de que a filiação a determinado Orixá tem como consequência um ser humano que carrega em si características que vão moldar esta pessoa em todos os aspectos de sua vida: desde o modo de se comportar, o seu caráter, o seu padrão emotivo, as suas aptidões, o seu temperamento, ou seja, aspectos que podem ser identificados como características da personalidade. A filiação a um determinado Orixá irá influenciar igualmente a sociabilidade de cada indivíduo, dado que filhos ou filhas de determinados Orixás têm maior afinidade com filhos ou filhas de certos outros Orixás, bem como inversamente falta de afinidade com filhos ou filhas de outros Orixás. A filiação a determinado Orixá irá moldar também o modo de ser de cada indivíduo em muitos outros aspectos, como por exemplo: cada Orixá tem cores que lhe são prediletas e outras que lhe são desagradáveis; cada Orixá terá comidas preferidas e comidas detestadas. Assim, a filiação a este ou àquele Orixá irá fazer

${ }^{6}$ Para esta questão dos diversos Orixás em cada pessoa, remeto aqui a KILEUY, O; OXAGUIÃ, V., (2009). 
igualmente com que esta pessoa deverá privilegiar o uso ou a proximidade de certas cores em suas roupas ou sua casa, bem como evitar trajar outras cores ou decorar com elas o ambiente em que vive. Também é de influencia da filiação aos Orixás a propensão a determinadas escolhas profissionais: algumas devem ser preferentemente escolhidas, outras devem ser deliberadamente evitadas.

Nestes poucos elementos que descreveram os âmbitos e as consequências da filiação a determinado Orixá, fica claro que este fator é determinante para o modo de ser, de se relacionar e de fazer escolhas de cada pessoa. Ou seja, o modo de ser, de se portar e agir, bem como de se comportar de cada indivíduo é claramente influenciado - segundo o Candomblé - pela filiação ao Orixá pessoal. E aqui chegamos ao ponto central da compreensão de ética no Candomblé: esta depende decisivamente da filiação ao Orixá, seja do Orixá principal (o Olori, o senhor da cabeça), seja do segundo ou terceiro Orixá. "Fala-se muitas vezes do orixá segundo (ori ekeji, 'a segunda cabeça'), do terceiro, que podem ter influência poderosa" (AUGRAS, 2008, p. 199). Se no início do texto se falou na intenção de indicar princípios a partir dos quais seria possível visualizar onde estaria ancorada uma ética pensada a partir do Candomblé, aqui vem a primeira indicativa clara: um dos princípios básicos para a ética no Candomblé é a filiação ao Orixá. Esta irá influenciar decisivamente o indivíduo tanto nos elementos de sua personalidade, como na sua forma de se portar, agir, se relacionar ou fazer escolhas. A determinação advinda da filiação ao Orixá abrange todos os aspectos da vida do indivíduo. Não é uma questão de atitude de âmbito religioso apenas: o todo de cada pessoa é marcado a partir desta filiação7.

Um segundo elemento importante para se fazer a relação entre filiação a determinado Orixá e ética no Candomblé é o fato de que esta não é entendida como estática, mas sim dinâmica. Para os iniciados na religião do Candomblé, a filiação a determinado Orixá não é apenas uma informação; ela é um verdadeiro programa

\footnotetext{
${ }^{7}$ Augras (2004), em seu estudo "Quizilas e Preceitos - Transgressão, reparação e organização dinâmica do mundo", mostra com grande riqueza de detalhes os múltiplos âmbitos de influência do Orixá na vida de seu filho, bem como o sistema de necessária reparação quando de transgressões.
} 
de vida. Durante toda a sua vida o fiel irá procurar viver e se comportar de tal forma a expressar o mais proximamente possível a filiação ao seu Orixá. Aqui se mostra um segundo elemento decisivo para a compreensão de ética no Candomblé a partir da filiação aos Orixás: é da busca pela vivência das características do Orixá (em todos os seus aspectos) que irá depender o equilíbrio da vida de cada pessoa. Se como dito anteriormente, a relação entre Orum e Aiyê é uma relação de equilíbrio, este se mostra decisivo na busca do indivíduo por viver de tal forma que a sua existência espelhe o melhor possível o referencial que é o seu Orixá pessoal: isto tanto nas cores a serem usadas ou nas comidas de sua preferência, como no seu comportamento para consigo mesmo (as virtudes que marcam sua personalidade) e para com os outros (as preferências e as dificuldades nas relações entre filhos de Orixás). Esta permanente busca de equilíbrio no que tange ao Orixá pessoal é uma busca por ser o que se é originalmente: existência descendente do Orum pela filiação concreta de um Orixá. A busca de uma vida que dinamize o equilíbrio entre Orum e Aiyê ou - do ponto de vista do indivíduo - uma vida que espelhe a filiação ao seu Orixá específico é no fundo a busca por uma conduta ética equilibrada. Não por princípios-padrões válidos para todos, mas por princípios pessoais que têm como parâmetro a filiação ao Orixá. Voltaremos à frente ainda a esta ideia de parâmetros múltiplos de compreensão de equilíbrio ou de forma de vida. Desta busca por um modo de ser que seja uma espécie de reflexo do Orixá pessoal é que decorre o processo de iniciação.

A pertença à religião do Candomblé não é resultado de um processo de conversão ou de simples adesão. Ela é decorrente do processo de iniciação. Assim, nenhum membro desta religião é iniciado para o Candomblé, como um cristão ao ser batizado, se torna membro do Cristianismo. Na tradição da religião dos Orixás a pertença se dá a uma determinada comunidade e através da iniciação ao Orixá pessoal. É pela iniciação que o fiel irá adentrar paulatinamente na experiência de seu Orixá pessoal e esta irá moldar o fiel ao longo do tempo de tal forma que este possa sempre mais viver o seu Orixá. Destarte, o referencial para a trajetória de 
vida do iniciado - o seu Orixá pessoal - é um parâmetro que vai sendo desvendado e conhecido e seguido sempre mais à medida que o seu Orixá pessoal é cultuado (cultivado) e experienciado. Assim se na tradição cristã, por exemplo, a reflexão e a busca pela compreensão da divindade é chamada de teo-logia, no Candomblé esta reflexão e busca poderia ser apropriadamente chamada de orixá-logia: a lógica ou a compreensão a partir dos Orixás.

\section{0 agir humano: uma orixalogia}

Na concepção do Candomblé, os Orixás são forças ou entidades não físicas, que controlam e regulam tanto os acontecimentos cósmicos como os fenômenos da natureza; eles determinam tanto a vida social, como a vida individual das pessoas. Se são por um lado forças anônimas - como por exemplo as forças do vento, do raio ou do rio que corre na natureza - e que em princípio não conhecem limites e que são distantes dos seres humanos; por outro lado os Orixás são apresentados com personalidades individuais, com desejos e caráter definidos, com histórias vividas e relações familiares constituídas. Estes Orixás, tanto em seu aspecto de energia da natureza como em seu aspecto personalizado, são forças que agem permanentemente em cada ser humano. Na linguagem personalizada, os Orixás são seres que conhecem as pessoas (especialmente os seus filhos) e lhes dão atenção; seres que têm uma relação afetiva para com os seus filhos; seres que tanto os podem consolar como também castigar. Nem tanto pela racionalidade se pode explicar e conciliar estas contradições; elas são percebidas, vivenciadas através da experiência religiosa.

O fiel, por seu lado, irá se aproximar cada vez mais de seu Orixá através do processo de iniciação. Por ele, o membro do Candomblé é introduzido no sistema de culto ao seu Orixá pessoal. É parte deste sistema toda uma série de elementos rituais: o iniciado irá aprender, por exemplo, as saudações de seu Orixá, as suas cantigas, irá aprender os passos de suas danças, irá aprender os mitos que lhe dizem respeito, as comidas e bebidas de seu Orixá e de tudo isto suas preferências e 
suas quizilas, isto é, as coisas que o Orixá não gosta. E assim por diante. Este processo do culto ao Orixá pessoal é uma via de duas mãos. Ao cultuar o Orixá ritualmente, o fiel irá cultivar um modo de vida correspondente. Seu cultivo ritual e seu cultivo de um modo de vida segundo o seu Orixá pessoal vai formando um conjunto de conhecimentos que se pode chamar de orixalogia: a lógica do Orixá pessoal. Esta lógica de aproximação do Orixá de seu filho ou filha e - por parte do iniciado - de aproximação, experiência e conhecimento de seu Orixá pessoal leva inclusive a um momento de unificação ritual: o momento do transe. Neste instante, o Orixá e sua filha ou seu filho vão formar uma unidade. É o momento em que origem e originado são uma só realidade, Orum e Aiyê se encontram em equilíbrio perfeito.

E a orixalogia é tanto um sistema de conhecimento cada vez mais aprofundado do Orixá pessoal, como também um conjunto de comportamentos, conhecido no Candomblé com o nome genérico de obrigações. O iniciado as tem para com o seu Orixá. As obrigações advindas de um modo amplo com origem no fato da filiação a determinado Orixá e de um modo mais direto e detalhado pelo processo de iniciação formam, para o fiel, o que se poderia chamar de seu código de ética pessoal. "Os deuses possuem cada qual seu temperamento que, de acordo com crenças populares, os seres humanos a eles consagrados herdam e reproduzem” (LÉPINE, 200o, p. 141). Falar de um código de ética ou de conduta no Candomblé é um tema, portanto complexo por se tratar sempre de algo por um lado especificamente relativo ao Orixá do iniciado e por outro ao processo de iniciação no qual o fiel se encontra. Mas ao mesmo tempo não se pode afirmar que não exista nesta religião uma noção de ética. Não há uma com princípios unificados e válidos para todos, pois “o adepto do candomblé somente presta conta de suas ações à sua divindade particular, com a qual ele pode contar para ter uma vida livre de desgraças, perdas e frustrações” (PRANDI, 2005, p. 148). Mas também não é um sistema sem referências onde cada qual pode fazer o que quiser: "São os tabus que definem o que o fiel não pode fazer e eles não são os mesmos para todos, dependendo do orixá da pessoa e de seu odu, uma espécie de regência mítica que 
acompanha o iniciado por toda a vida" (PRANDI, 2005, p. 148). Mesmo sendo duas pessoas filhas do mesmo Orixá, seu código de conduta de comportamento tem algo em comum - por conta da filiação ao mesmo Orixá - mas tem sempre algo de especificamente pessoal - por conta do chamado Odu. Este conceito (Odu) designa inicialmente cada figura (desenho) que aparece no jogo de búzios, mas a palavra também significa destino, indicando que cada combinação dos búzios jogados tem um significado diferenciado, está indicando um destino. Tendo demonstrado a lógica que segue a possibilidade de se pensar os referenciais para uma ética no Candomblé e como esta pode ser extremamente personalizada no agir de cada filha ou filho de santo, se irá apontar agora para alguns conceitos importantes para se pensar esta ética.

\section{Elementos de uma ética orixalógica}

É muito difícil encontrar conceitos que possam qualificar as diversas formas de se entender uma ética. Qualquer qualificação seria uma simplificação que incorre em reducionismo. Consciente deste problema far-se-á aqui um reducionismo para apontar um elemento importante para a possibilidade de se pensar ética no Candomblé. A ética no Candomblé é uma ética relacional e não uma ética de valores (ou virtudes) gerais válidos para o todo. Prandi, em sua obra "Os Candomblés de São Paulo” (1991) irá afirmar justamente que não há nesta religião "a ideia de que um comportamento pode ou deve ser regido por normas gerais partilhadas que orientam a ação na vida cotidiana” (p. 152). E continua: “A ideia de ‘obrigação’ não está relacionada assim, nem à ideia de regras morais para reger a vida e nem a comportamentos generalizados" (p. 154). A constatação da inexistência de uma norma geral de comportamentos fará com que o este autor qualifique o Candomblé como uma religião a-ética (PRANDI, 1991, p. 152-154). Assim, concordamos aqui com Prandi na afirmação de que na religião do Candomblé não há normas gerais de conduta para o todo. A isto se está chamando aqui de ética de princípios (ou de valores universais ou de virtudes). A falta de princípios gerais validos para o todo no Candomblé não implica, entretanto afirmar 
que não haja para os adeptos desta religião elementos que possam servir de referências para se distinguir o que é certo e o que é errado, o que deve ser feito e o que deve ser evitado. O próprio Prandi (2005), num escrito posterior ("Segredos Guardados”), irá recolocar a mesma questão, não mais utilizando o conceito de religião a-ética para o Candomblé:

As noções de certo e errado, as pautas de direitos e deveres, as interdições, assim como as regras de lealdade e reciprocidade, são moldadas na relação entre o seguidor e seu orixá, entre o filho humano e o pai divino. Esta relação está acima de qualquer outra coisa, e acredita-se que a personalidade do filho reflete a personalidade do orixá que é seu pai ou mãe no plano mítico, o que lhe atribui por herança uma gama de comportamentos e atitudes aceitos e justificados pelos mitos dos orixás e que podem contrastar muito com os modelos de conduta cristãos (PRANDI, 2005, p. 148).

E continua:

Mais uma vez, não há um modelo geral válido para todos, pois tudo depende da origem mítica de cada um; são múltiplas as origens possíveis; são muitos os orixás dos quais os homens e mulheres descendem. $\mathrm{Na}$ lógica politeísta do candomblé, não se pode esperar que filhos de orixás diferentes tenham os mesmos comportamentos, qualidade morais, desejos e aspirações (PRANDI, 2005, p. 148-149).

Novamente, o que aqui está descrito é exatamente um conceito de ética que neste texto está sendo qualificada como ética relacional: os referenciais para o comportamento dependem do lugar que o indivíduo ocupa nesta teia de relações com o seu Orixá e o seu Odu, destino que é visto (aberto) através do jogo de búzios. A ética do Candomblé é, pois uma ética orixalógica, seguindo sempre a lógica da relação do adepto com o seu Orixá (ou os seus Orixás, na ideia de poder cada indivíduo ter a influência de mais de um Orixá) e o seu respectivo Odu. Mas mesmo sendo esta ética orixalógica de princípio relacional, portanto sem um padrão geral unificado de comportamento, como pode o adepto ter elementos para distinguir em cada caso concreto, o que seria certo do que seria errado, o que seria desejável do que se deveria evitar? 
Voltemos aqui à ideia exposta anteriormente na cosmovisão de mundo dos iorubanos com a ideia da forma de existência Orum como existência que contém em si todas as existências individualizadas e finitas no tempo e espaço. Foi afirmado que a existência humana e tudo o que lhe diz respeito acontece a partir do Orum, é uma existência descendente. No conceito Orum está não apenas a compreensão de lugar-origem das existências, mas também estão no Orum todos os acontecimentos das existências concretas. Assim o Orum é também a origem de todo sentido, de tudo o que está em ordem. O Orum é, além de "reserva de existência", também "reserva de sentido". As existências individualizadas e concretas, descendentes, portanto, têm no Orum além da sua possibilidade de existir, também o sentido de seu existir; todo o sentido está já ali presente. Em outras palavras, poder-se-ia dizer que no Orum está já consignado todo o destino de cada existência individual, dado que tudo o que há (na forma descendente) está como um todo dentro do Orum. Para a discussão da ética no Candomblé, esta ideia é bastante central, pois no Orum está já toda a existência, em sua finalidade inclusive. Mas como acessar este conhecimento sobre o destino da existência, se este está consignado no Orum?

É a compreensão de que tudo está no Orum que sustenta na cosmovisão do Candomblé os sistemas divinatórios, ou seja, as consultas. Sem adentrar na temática das técnicas e dos diferentes sistemas divinatórios dos iorubanos, se quer apenas acenar aqui para o fato de que eles só são possíveis dentro da compreensão de que o Orum condensa toda a possibilidade de existência. Assim, uma consulta no processo divinatório não é um exercício de futurologia ou adivinhação, nem de acerto ou erro por magia. Pelo sistema divinatório, a consulta se faz ao Orum, ou seja, o processo de consulta divinatória é um acesso ao todo, mesmo que feito de forma limitada, por um momento e fragmentada. Mas a consulta é um momento de olhada para dentro do todo, donde se poderá então influir dele algo para o acontecer da individualidade particular e temporal. A consulta seria uma espécie de existência no reverso: se cada existência individual é sempre uma existência descendente do Orum, um de-lá-para-cá, sem esvair ou esgotar a origem 
permanecendo ela na totalidade, no momento da consulta divinatória há uma mirada de-cá-para-lá. Por ela se consegue acessar (ver) algo do todo. Daí se influi que a consulta diz algo ao atual não como um palpite ou um desejo ou a explanação de uma possibilidade, mas diz sim algo do que é.

Concretamente, no Candomblé, o sistema divinatório do jogo de búzios revela os Odus. Como já dito, denomina-se Odu cada combinação das 16 conchinhas (búzios) que são jogadas (ou abertas, na linguagem do Candomblé). Cada Odu representa um destino. Ele é uma pequena mirada para dentro do Orum e cabe a quem joga interpretar as combinações. Este sistema dos Odus é deveras complexo e exige de quem joga saber uma série bastante longa de combinações matemáticas e seus significados. A pessoa mais conhecida a dominar este sistema de consulta aos Odus no Brasil foi Agenor Miranda Rocha (1907-2004), conhecido pelo povo do Candomblé como "Professor Agenor" e ele denominava a pessoa que joga os búzios de olhador: "O olhador tem que ter sabedoria para desvendar o Odu completamente, porque nenhuma receita geral é assim completa. Cada caso é um caso" (ROCHA, 1999, p. 15). Em sua obra "Caminhos de Odu", Professor Agenor colocou em público a sua base de interpretação dos Odus. Há aqui um detalhe a ser chamado a atenção: quem consulta o oráculo é chamado no Candomblé de Oluô, função traduzida por Professor Agenor como "olhador, sacerdote que joga búzios" (ROCHA, 1999, p. 199). "Os oluôs (òlùwò = 'senhor que possui o segredo') foram designados pelos orixás para receber o cargo de 'olhador do oráculo' particularizado do Axé em que é iniciado” (KILEUY; OXAGUIÃ, 2009, p. 60). Portanto, o conteúdo do oráculo não sai da pessoa que faz o jogo. Esta apenas olha. No caso, olha (e interpreta) algo do Orum que se lhe mostra.

No que tange à ética relacional, onde não há um padrão geral comum a ser seguido, o sistema de consulta aos Odus passa a ter um papel muito importante para se saber como proceder em cada situação concreta. "Nada se faz sem que antes se consulte o oráculo. Quanto mais séria a questão a ser resolvida, maior a responsabilidade da pessoa que faz o jogo", afirma Professor Agenor (ROCHA, 
1999, p. 25). E como a consulta ao oráculo é em princípio um ato de relação entre o Aiyê e o Orum, este sistema também é regido pela norma da oferta e retribuição. Assim, o primeiro passo da consulta é sempre o ebó (a oferenda) (ROCHA 1999, p. 15). Destarte mantém-se o equilíbrio da existência, pois esta depende da relação dinâmica entre Orum e Aiyê. E o equilíbrio ocorre pela chamada troca de Axé. Como força dinamizadora da relação entre Orum e Aiyê, todas as ações que objetivam este equilíbrio dos níveis da existência, são ações liberadoras de Axé. O equilíbrio da existência demanda Axé. Fecha-se assim o círculo da busca ética no Candomblé: a existência em equilíbrio.

\section{0 equilíbrio da existência: uma ética para além da dualidade bem-mal}

Se a ideia de ética encerra uma ideia de ordem, o viver de maneira ética corresponderia, pois a uma existência tal em que as coisas estivessem em ordem. A finalidade da ordem na compreensão do Candomblé não é teleológica. Ela é relacional e imanente. No aqui e no agora as coisas estarem em ordem significa a existência disposta de tal maneira que - no limite - a relação entre Orum e Aiyê esteja em equilíbrio.

Dado que não se trata de uma ética de valores gerais fixos, o equilíbrio é composto e recomposto por ações e vivências que podem ser múltiplas. Não há um padrão único de equilíbrio. Para cada percepção de desequilíbrio há ações possíveis para se buscar o reequilíbrio. Assim, se há por exemplo algum desentendimento familiar, isto é interpretado como sinal de que algo está desequilibrado. O oráculo (no jogo de búzios) é consultado e a interpretação do Odu correspondente irá indicar ações a serem realizadas para recompor o equilíbrio da situação. Uma ética relacional é dinâmica e de composições.

Assim sendo, nesta compreensão de ética relacional do Candomblé não apenas inexiste a ideia de um padrão de comportamento, como também inexiste a ideia de figuras exemplares de comportamento ético que possam servir para o todo. 
Diferentemente de muitas outras tradições religiosas, não há no Candomblé alguma figura única que possa ser seguida, como modelo de padrão de comportamento a exemplo do que é Jesus Cristo para o Cristianismo, Siddhartha Gautama para o Budismo, Mohammed para o Islã, etc. Cada filha ou filho de Orixá irá seguir o seu Orixá e à maneira revelada pelos Odus. Entende-se que os filhos de cada Orixá específico tenham características gerais de comportamento que sejam de alguma forma comuns (pela filiação do Orixá). Se não há uma ideia geral de padrão de comportamento, há uma certa ideia de padrão de comportamento para os filhos de um determinado Orixá. Para citar apenas alguns exemplos e com descrições recortadas: "Os filhos de Ogum costumam ser [...] dinâmicos, impulsivos, intransigentes e, em alguns momentos, mostram-se violentos, sem saber equilibrar a convivência social" (KILEUY; OXAGUIÃ, 2009, p. 231); "Os filhos de Oxóssi gostam de zelar pelos amigos e pela família, mesmo que estes exijam mais do que ele posa oferecer. Possuem um grande senso de proteção e de responsabilidade para com seus familiares" (KILEUY; OXAGUIÃ, 2009, p. 243); as pessoas de Obá "têm grande senso de justiça e amizade, mostrando-se às vezes severas e carrancudas. [...] quando ofendidas profundamente, tornam-se rancorosas; procuram a qualquer momento vingar-se de quem as magoou" (KILEUY; OXAGUIÃ, 2009, p. 288).

Há muitos escritos em torno desta temática das características dos filhos de determinados Orixás. Assim nesta obra de Kileuy e Oxaguiã (2009) há inclusive um longo capítulo sobre o tema (p. 220-326). Outra publicação importante nesta temática é a "Orixás” de Verger (1997b), comparando os cultos aos Orixás na África e no Brasil, onde o autor para cada Orixá também explana as características de seus filhos e filhas, chamando isto de arquétipo. Outra publicação sobre a temática a se fazer menção aqui é a obra "Os Orixás e a Personalidade Humana" escrita por uma liderança religiosa do próprio Candomblé, o Babalorixá Mário César Barcellos (1990), onde o autor descreve tanto as características positivas quando as negativas da personalidade dos filhos de cada Orixá, bem como as possibilidades de relacionamentos tanto entre pessoas de Orixás diferentes bem como de pessoas 
filhas do mesmo Orixá. Na proposta deste autor aparece claramente a grande diversidade de possibilidades de comportamentos das pessoas a partir justamente do que chamou acima de orixalogia.

Se cada adepto do Candomblé faz deste seguimento específico ao seu Orixá uma forma concreta para a ação e o comportamento pessoal, isto é, para uma ética de vida, ou se o seguimento do Orixá é entendido e vivido tão somente como o cumprimento de um ritualismo desligado da vida prática, já é uma outra questão. Prandi (2005, p. 141) irá chamar esta tendência de "hipertrofia ritual e falência moral”. A avaliação da distância existente entre proposta de vivência religiosa no Candomblé e a prática cotidiana dos iniciados já é uma temática que não cabe neste texto. Nesta possível discrepância que existe entre teoria e prática na vida de adeptos de um sistema religioso, o Candomblé certamente não é uma exceção.

Se como afirmado acima, na busca pelo equilíbrio da existência não há um padrão único a ser seguido, mas padrões múltiplos dependendo da filiação ao Orixá e da revelação do Odu, esta busca também será diversificada conforme o nível de iniciação de cada adepto e/ou de função que o adepto exerce dentro da comunidade do Candomblé. A iniciação é um processo de diversas etapas e a cada etapa cabem as respectivas obrigações. O equilíbrio da existência individual é algo também dinâmico em relação ao tempo de iniciação. A cada etapa há o seu respetivo equilíbrio a ser buscado.

A ética da existência em equilíbrio entre Aiyê e Orum, entre o adepto e seu Orixá substitui no Candomblé a dualidade bem-mal. Não há coisas que sejam por princípio boas, como não há coisas que sejam por princípio más. "O bem e o mal, pra mim não existe o bem e o mal. Eu estou dentro duma... eu estou dentro do universo, o que é mal pra mim pode ser bom pra você. O que é mal pra o meu orixá, aí sim é o mal para mim”, diz um adepto a Prandi (1991, p. 146). Novamente volta a ideia de que a definição de conduta ética (o que é bem e o que é mal) não é feita por princípios, mas pela relação com o Orixá. Algo está correto se estiver de acordo (em equilíbrio) na relação com o Orixá e sua forma de manifestar-se pelo Odu. 
Da falta de conceito de princípios que definam as coisas como boas ou más, também decorre que na ética relacional do Candomblé não há a ideia nem de pecado, nem de perdão. Se há algo percebido como desequilibrado seja em termos de relacionamento, de saúde, de finanças, de atuação profissional, de família, de qualquer âmbito da vida, necessário se faz alguma ação para reequilibrar a situação. Assim, ao invés do binômio pecado-perdão, há a lógica do equilíbrio a ser mantido ou refeito. E este acontece pela dinamização do Axé.

\section{Considerações finais}

A intenção das ideias expostas neste texto era apontar para a possibilidade de se pensar a ética a partir da religião do Candomblé. A temática merece muito aprofundamento, e há certamente outros autores que estão fazendo. E isto é importante a nosso modo ver, pois se trata de mostrar não apenas que existem diferentes padrões de ética, mas também que há padrões culturais diferentes de se pensar a própria origem da ética. E de forma alguma isto deveria levar a discutir se este ou aquele modelo ético é mais adequado para a vida pessoal ou social, para a existência humana ou existência ecológica. Mais importante que isto seria poder fazer dialogar estes diversos modelos de sistemas éticos, dado que isto enriqueceria os modos de pensar as condutas humanas e suas convivências.

Para pensar a ética no Candomblé, o que parece central é a ideia de que se trata de uma ética sempre relacional: relacionada com o Orixá pessoal do qual se entende ser cada pessoa filha ou filho e relacionada com a manifestação deste Orixá em seu destino concreto, o Odu. Por ser uma ética relacional e pessoal, decorre que dificulta pensar em padrões de valores. Há a impressão de uma certa ou total volatilidade permanente e por isso a impressão de uma ausência de conceituação ética. Mas o desafio ou a dificuldade de se pensar uma ética relacional como aqui proposto é justamente pelo fato de que este conceito de ética é sempre dinâmico e de composições múltiplas. 


\section{REFERÊNCIAS}

AUGRAS, M. O duplo e a metamorfose. Petrópolis: Vozes, 2008.

AUGRAS, M. Quizilas e preceitos - transgressão, reparação e organização dinâmica do mundo. In: MOURA, C. E. M. (org.). Culto aos Orixás. Rio de Janeiro: Pallas, 2004, p. 157-196.

BARCEllos, B. M. C. Os Orixás e a Personalidade Humana. Rio de Janeiro: Pallas, 1990.

BERKENBROCK, V. J. Elementos de uma Antropologia Religiosa a partir do Candomblé. REB, Petrópolis, ano 74, n. 296, p. 847-866, 2014.

DUSSEL, H. Ética da Libertação. Petrópolis: Vozes, 2012.

JAGUN, M. de. Ori: a Cabeça como Divindade. Rio de Janeiro: Litteris, 2015.

KILEUY, O.; OXAGUIÃ, V. de. O Candomblé bem explicado. Rio de Janeiro: Pallas, 2009.

KRAMERS, R. P. Confúcio. In: BRUNNER-TRAUT, E. (org.). Os Fundadores das Grandes Religiões. Petrópolis: Vozes, 2000, p. 179-202.

LÉPINE, C. Os estereótipos da personalidade no Candomblé Nagô. In: MOURA, C. E. M. (org.). Candomblé: Religião do Corpo e da Alma. Rio de Janeiro: Pallas, 2000, p. 139-166.

MARCHIONNI, A. Ética: a arte do bom. Petrópolis: Vozes, 2010.

MATTOSO, K. M. de Q. Ser Escravo no Brasil. Petrópolis: Vozes, 2016.

PRANDI, R. Mitologia dos Orixás. São Paulo: Companhia das Letras, 2001.

PRANDI, R. Os Candomblés de São Paulo. São Paulo: Huicitec-Edusp, 1991.

PRANDI, R. Segredos Guardados. São Paulo: Companhia das Letras, 2005.

ROCHA, A. M. Caminhos de Odu. Rio de Janeiro: Pallas, 1999.

SANTOS, J. E. dos. Os Nago e a Morte. 14 ed. Petrópolis: Vozes 2012.

TORRES, J. C. B. (org.). Manual de Ética - Questões de ética teórica e aplicada. Petrópolis: Vozes, 2014.

VERGER, P. F. Lendas Africanas dos Orixás. 4 ed. Salvador: Corrupio, 1997a.

VERGER, P. F. Orixás. Salvador: Corrupio, $1997 \mathrm{~b}$. 